\title{
Spread of the florfenicol resistance flo $R$ gene among clinical Klebsiella pneumoniae isolates in China
}

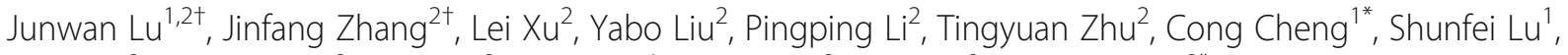
Teng $\mathrm{Xu}^{2}$, Huiguang $\mathrm{Yi}^{2}$, Kewei $\mathrm{Li}^{2}$, Wu Zhou' ${ }^{1}$, Peizhen $\mathrm{Li}^{2}$, Liyan $\mathrm{Ni}^{3}$ and Qiyu Bao ${ }^{2^{*}}$

\begin{abstract}
Background: Florfenicol is a derivative of chloramphenicol that is used only for the treatment of animal diseases. A key resistance gene for florfenicol, floR, can spread among bacteria of the same and different species or genera through horizontal gene transfer. To analyze the potential transmission of resistance genes between animal and human pathogens, we investigated floR in Klebsiella pneumoniae isolates from patient samples. flo $R$ in human pathogens may originate from animal pathogens and would reflect the risk to human health of using antimicrobial agents in animals.

Methods: PCR was used to identify floR-positive strains. The floR genes were cloned, and the minimum inhibitory concentrations (MICs) were determined to assess the relative resistance levels of the genes and strains. Sequencing and comparative genomics methods were used to analyze floR gene-related sequence structure as well as the molecular mechanism of resistance dissemination.

Results: Of the strains evaluated, 20.42\% (67/328) were resistant to florfenicol, and 86.96\% (20/23) of the floRpositive strains demonstrated high resistance to florfenicol with MICs $\geq 512 \mu \mathrm{g} / \mathrm{mL}$. Conjugation experiments showed that transferrable plasmids carried the flo $R$ gene in three isolates. Sequencing analysis of a plasmid approximately $125 \mathrm{~kb}$ in size (pKP18-125) indicated that the floR gene was flanked by multiple copies of mobile genetic elements. Comparative genomics analysis of a 9-kb transposon-like fragment of pKP18-125 showed that an approximately 2-kb sequence encoding lysR-floR-virD2 was conserved in the majority $(79.01 \%, 83 / 105)$ of flo $R$ sequences collected from NCBI nucleotide database. Interestingly, the most similar sequence was a 7-kb fragment of plasmid pEC012 from an Escherichia coli strain isolated from a chicken.

Conclusions: Identified on a transferable plasmid in the human pathogen $K$. pneumoniae, the floR gene may be disseminated through horizontal gene transfer from animal pathogens. Studies on the molecular mechanism of resistance gene dissemination in different bacterial species of animal origin could provide useful information for preventing or controlling the spread of resistance between animal and human pathogens.
\end{abstract}

Keywords: Florfenicol, floR, Klebsiella pneumoniae, Plasmid, Human pathogen

\footnotetext{
* Correspondence: 113246570@qq.com; baoqy@genomics.cn

†Junwan Lu and Jinfang Zhang contributed equally to this work.

${ }^{1}$ School of Medicine and Health, Lishui University, Lishui 323000, China

${ }^{2}$ School of Laboratory Medicine and Life Sciences/Institute of Biomedical

Informatics, Wenzhou Medical University, Wenzhou 325035, China

Full list of author information is available at the end of the article
}

(c) The Author(s). 2018 Open Access This article is distributed under the terms of the Creative Commons Attribution 4.0 International License (http://creativecommons.org/licenses/by/4.0/), which permits unrestricted use, distribution, and reproduction in any medium, provided you give appropriate credit to the original author(s) and the source, provide a link to the Creative Commons license, and indicate if changes were made. The Creative Commons Public Domain Dedication waiver (http://creativecommons.org/publicdomain/zero/1.0/) applies to the data made available in this article, unless otherwise stated. 


\section{Background}

Florfenicol, which is only used to treat animal infections, is a derivative of chloramphenicol that is active against chloramphenicol-resistant isolates [1]. Resistance to chloramphenicol occurs mainly through the production of inactivating enzymes called chloramphenicol acetyl transferases (CATs) [2] and chloramphenicol exporters, such as CmlA [3]. Over the past decade, most reports have demonstrated that the bacteria causing animal respiratory diseases show high resistance levels to chloramphenicol but are susceptible to florfenicol [4]. However, the resistance levels and number of bacteria that are resistant to florfenicol have increased due to the widespread use of florfenicol in the treatment of animal diseases [5-7]. A study on 1001 bacterial isolates showed that the resistance rates for trimethoprim/sulfamethoxazole and tetracycline were $3.0 \%$ and $14.7 \%$ in Actinobacillus pleuropneumoniae and $6.0 \%$ and $81.8 \%$ in S. suis, respectively, while the resistance rate for florfenicol was $<1 \%$ for all strains [8]. Other reports have cited different resistance rates. In Australia, 2.0\% and 6.0\% of A. pleuropneumoniae and Pasteurella multocida strains isolated from pig respiratory infections were resistant to florfenicol, respectively [9]. The resistance rate of E. coli strains from canine urinary tract infections to florfenicol was higher than that of other pathogens: $31.6 \%$ (36/114) [5].

The first florfenicol resistance gene, pp-flo (renamed flo), was identified on a plasmid in the fish pathogen Photobacterium damselae subsp. piscicida in 1996 [10]. The floR gene is closely related (97\% identity) to the flo gene [11], and their proteins share $47 \%$ amino acid sequence identity with the CmlA protein. The floR gene was first reported in 1999 on the chromosome of the worldwide epidemic strain Salmonella enterica serovar Typhimurium DT104 [11]. The primary source of human DT104 infections was thought to be animal populations, with both direct contact and foodborne modes of transmission [12]. The IncC plasmid R55, which was initially described to be capable of conferring non-enzymatic chloramphenicol resistance in the 1970s, was then identified in Klebsiella pneumoniae [13]. Currently, nine florfenicol resistance genes $[f l o R, f l o R v, f l o S t, f \operatorname{ex} A, f \operatorname{ex} B, \operatorname{pex} A$, cfr, optrA and estDL136] have been identified. With the exception of $c f r$ and estDL136, which encode a 23S rRNA methyltransferase and a hydrolase, respectively, all of the genes encode exporters [14-18]. The floR gene and its analogs have mainly been identified in gram-negative bacteria, whereas the other resistance genes have mainly been detected in gram-positive bacteria [15-17].

Similar to other resistance genes, floR has been identified on both chromosomes and plasmids and has often been associated with mobile genetic elements and genomic islands [19, 20]. Mobile genetic elements enable translocation of the floR gene between DNA molecules, such as chromosomes and plasmids. A plasmid carrying the floR gene can spread among bacteria of the same and different species or genera via conjugation or transformation, thereby disseminating resistance [21]. Bacteria generally obtain multiple resistance genes through the horizontal transfer of plasmids carrying resistance genes [22].

K. pneumoniae, which is a member of the Enterobacteriaceae, is an opportunistic pathogen for both animals and humans. This bacterium is pervasive in the natural environment and benignly colonizes the gastrointestinal tracts of healthy humans and animals. However, the bacterium is also capable of causing a wide range of diseases in humans and different animal species [23]. K. pneumoniae strains are a common cause of health-care associated infections including pneumonia, urinary tract infections (UTIs), and bloodstream infections for critically ill and immunocompromised patients. These strains also infect healthy people in community settings, causing severe infections including pyogenic liver abscess, endophthalmitis, and meningitis [24]. For example, in animals, $K$. pneumoniae strains are well documented to cause mastitis and wounds in cattle [25]; endometritis, cystitis, and liver abscess in horses; tracheitis and wounds in birds; cystitis, phlebitis and otitis externa in dogs; and cystitis in cats [26]. K. pneumoniae has also been associated with classical foodborne disease outbreaks [19]. Notably, the prevalence of antibiotic resistance is increasing among Enterobacteriaceae, including $K$. pneumoniae $[23,27]$. In this study, we used multiple genetic approaches to investigate the floR gene in $K$. pneumoniae isolates of human origin and to further demonstrate the potential transmission of this resistance determinant between animal and human pathogens.

\section{Methods \\ Bacterial strains}

The 328 non-duplicate $K$. pneumoniae strains used in this work were isolated from patient samples at the First Affiliated Hospital of Wenzhou Medical University in Wenzhou, China, from 2010 to 2014. This sample set included all $K$. pneumoniae strains collected during this time frame. Among these isolates, 55 were isolated in 2010, 109 in 2011, 55 in 2013 and 109 in 2014. The strains were identified using the Vitek-60 microorganism auto-analysis system (BioMerieux Corporate, Craponne, France).

\section{PCR amplification of the floR gene}

Total genomic DNA was extracted from the 328 isolates using AxyPrep Bacterial Genomic DNA Miniprep kits (Axygen Scientific, Union City, CA, USA). Template DNA was screened for the floR gene using a PCR method. According to the conserved floR gene-related 
regions of the $K$. pneumoniae genome obtained from a pool of strains mainly from this work [28], floR gene screening primers were designed and named $\mathrm{P}_{\mathrm{SCR}-\mathrm{F}}$ and

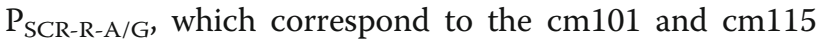
primer sequences, respectively [29]. The sequence of the forward primer $\mathrm{P}_{\mathrm{SCR}-\mathrm{F}}$ was 5'-TTTGGTCCGCTCTC AGAC-3'. Two variants of the reverse primer were used due to a single nucleotide polymorphism (A/G) identified in the region where the primer was designed: 5'-CGAGAAGAAGACGAAGAAG-3' (P ${ }^{\text {SCR-R-A }}$ ) and

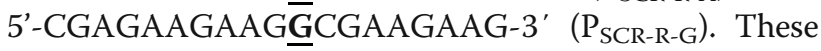
primers yield a product $496 \mathrm{bp}$ in length. PCR amplification was carried out under the following conditions: an initial denaturation of $5 \mathrm{~min}$ at $95{ }^{\circ} \mathrm{C}$; 35 cycles of denaturation $\left(94{ }^{\circ} \mathrm{C}\right.$ for $\left.45 \mathrm{~s}\right)$, annealing $\left(58{ }^{\circ} \mathrm{C}\right.$ for $\left.45 \mathrm{~s}\right)$, and extension $\left(72{ }^{\circ} \mathrm{C}\right.$ for $\left.90 \mathrm{~s}\right)$; and a final extension step at $72{ }^{\circ} \mathrm{C}$ for $10 \mathrm{~min}$ [29]. The PCR products were purified using a MinElute PCR Purification kit (QIAGEN China, Shanghai, China) and sequenced by Sanger sequencing (in this work, all the PCR products and cloned fragments were sequenced by Sanger sequencing). The nucleotide sequences were analyzed and compared using the BLAST program (http://www.ncbi.nlm.nih.gov/ BLAST).

\section{Antimicrobial susceptibility testing}

Antimicrobial susceptibility testing performed via the agar dilution method in accordance with the guidelines of the Clinical and Laboratory Standards Institute (CLSI document M100-S27, 2017) was used to determine the minimum inhibitory concentrations (MICs) [30]. The resistance threshold values $(32 \mu \mathrm{g} / \mathrm{mL})$ for both chloramphenicol and florfenicol were chosen according to the guidelines of CLSI document M100-S27 (2017) [30] and a publication for E. coli [31], respectively. E. coli ATCC 25922 was used as a quality control strain.

\section{Pulsed-field gel electrophoresis (PFGE)}

To assess the epidemiology of clinical isolates with floR genes, genomic DNA from K. pneumoniae isolates harboring floR genes was prepared for PFGE typing and digested with $40 \mathrm{U}$ of $\mathrm{Xba}$ I (Takara, Dalian, China). The protocol and the $\mathrm{Xba}$ I restriction patterns of genomic DNA from the isolates were analyzed and interpreted according to initial criteria [32]. The Bio-Rad Quantity One program was used to analyze the PFGE results, and a minimum spanning tree was constructed using a categorical coefficient with unweighted pair group method with arithmetic mean (UPGMA) clustering [33].

\section{Plasmid DNA extraction and sequencing}

For plasmid (pKP18-125) sequencing, the transconjugant KP18/EC600 was incubated overnight in $5 \mathrm{~mL}$ of Luria-Bertani broth at $37^{\circ} \mathrm{C}$ for approximately $16 \mathrm{~h}$ to an optimum optical density $\left(\mathrm{OD}_{600}\right)$ of $1.5 \pm 0.2$. The plasmid was then extracted using the alkaline lysis method as described previously [34]. Plasmid DNA was sequenced via Illumina HiSeq-2000 and Pacific Bioscience sequencing methods at the Beijing Genomics Institute (Beijing, China). Reads derived from the HiSeq-2000 sequencing were initially assembled de novo using SOAPdenovo software to obtain contigs of the plasmid. Pacific Bioscience sequencing reads of approximately $10-20 \mathrm{~kb}$ in length were mapped onto the primary assembly to scaffold the contigs. The gaps were filled either by remapping the short reads from HiSeq-2000 sequencing or by PCR product sequencing of the gaps. Glimmer software was used to predict protein-coding genes with potential open reading frames (ORF) > $150 \mathrm{bp}$ [35]. Gview was used to construct basic plasmid features [36]. BLASTX was used to annotate the predicted protein-coding genes against the non-redundant protein database using an e-value threshold of $1 \mathrm{e}-5$.

\section{Collection and processing of floR gene-related sequences} In addition to the pKP18-125 sequence, other sequences containing the floR gene were obtained from the NCBI nucleotide database using floR, pp-flo, flo, cmlA-like, floRv and floSt as key terms. The resulting sequences were filtered, and only sequences containing a complete floR gene more than $9 \mathrm{~kb}$ in length (with approximately $4 \mathrm{~kb}$ both upstream and downstream of the floR gene) were retained. Multiple sequence alignments were performed using mafft with the 9-kb floR gene-related fragment of pKP18-125 (KY082186) as a reference [32], and the sequences were clustered with an identity of $80 \%$. The sequence with greatest similarity to the other sequences in each cluster was chosen as a candidate for orthologous analysis. Orthologous groups of genes from the candidate sequences were identified using BLASTP and InParanoid [37]. The sequence retrieval, statistical analyses and other bioinformatics tools used in this study were accomplished using Python and Biopython scripts [38].

\section{Cloning experiments}

To identify and clone floR genes, we PCR amplified a fragment including the floR ORF sequence and its upstream 354-bp potential promotor region from strains positive for the floR gene. A set of PCR primers (P ORF-F and $\left.\mathrm{P}_{\mathrm{ORF}-\mathrm{R}}\right)$ was designed using the $K$. pneumoniae plasmid pR55 sequence (JQ010984.1) as a reference. The primer sequences of $\mathrm{P}_{\mathrm{ORF}-\mathrm{F}}$ and $\mathrm{P}_{\mathrm{ORF}-\mathrm{R}}$ were 5'-GTCG AGAAATCCCATGAGTTCA-3' and 5'-CAGACAGGA TACCGACATTCAC-3', respectively. The PCR products were eluted from agarose gels and ligated into the pMD18 vector (TaKaRa, Dalian, China). Each recombinant plasmid (pMD18-floR) was transformed into E. coli 
JM109 using the calcium chloride method, after which the bacterial colonies were grown on Luria-Bertani agar plates supplemented with ampicillin $(100 \mu \mathrm{g} / \mathrm{mL})$. The recombinant plasmids were isolated and digested with restriction enzymes to confirm insertion of a floR fragment of approximately $1600 \mathrm{bp}$ in length. Each cloned floR fragment was analyzed by Sanger sequencing from a purified transformant and was further compared to the reference floR gene (JQ010984.1) using the BLASTN program.

\section{Conjugation experiments}

To examine the conjugation potential of resistance gene-harboring pKP18-125, we used rifampin-resistant EC600 as a recipient strain in a biparental mating, which was performed overnight at $37^{\circ} \mathrm{C}$ on sterile nitrocellulose filters as previously described [39]. The transconjugants were selected on Mueller-Hinton agar plates containing $1200 \mu \mathrm{g} / \mathrm{mL}$ of rifampin and $16 \mu \mathrm{g} / \mathrm{mL}$ of florfenicol [40]. Plasmid DNA was extracted from transconjugants, and the presence of the floR gene was verified by PCR and PCR product sequencing. The plasmid (pKP18-125) of one transconjugant (KP18/EC600) was sequenced in full to verify that the floR gene was encoded on this transferable plasmid.

\section{Results}

\section{floR gene detection and sequencing}

Approximately $7.01 \%$ (23/328) of the isolates were positive for floR (Table 1). Of the 23 floR-positive strains, 4, 8, 4 and 7 strains were isolated in 2010, 2011, 2013 and 2014, respectively. The positive rates were similar among the strains collected from different years $(7.27 \%[4 / 55]$ in 2010, 7.34\% [8/109] in 2011, 7.27\% [4/55] in 2013 and $6.42 \%$ [7/109] in 2014). Twenty-two fragments containing the $f l o R$ ORF and their upstream potential promotor regions were successfully cloned; all the cloned ORF sequences shared approximately $99 \%$ nucleotide sequence identity. No amino acid variants were identified in the cloned ORFs.

\section{Florfenicol and chloramphenicol MICs of the strains}

The MICs of florfenicol and chloramphenicol were determined for the 328 clinical isolates, 3 transconjugants and transformants with cloned floR genes. The MIC results showed that 57 of the 328 clinical isolates (17.38\%) were resistant to both florfenicol and chloramphenicol, whereas $67(20.42 \%)$ and $113(34.45 \%)$ of the strains were resistant to florfenicol and chloramphenicol, respectively. A total of $7.62 \%(25 / 328)$ and $11.59 \%$ (38/ 328 ) of the strains were resistant to florfenicol and chloramphenicol, respectively, with MIC values $\geq 512 \mu \mathrm{g} /$ $\mathrm{mL}$, and $64.93 \%(213 / 328)$ of the strains were susceptible, with MIC values $<32 \mu \mathrm{g} / \mathrm{mL}$ for both antibacterial agents.

The strains positive for the floR gene had much higher MIC values for both florfenicol and chloramphenicol than the floR-negative strains. Of the 23 floR-positive strains, $95.65 \%(22 / 23)$ showed high MIC values to florfenicol $(\geq 512 \mu \mathrm{g} / \mathrm{mL})$ (Table 2). Among the 305 strains negative for the floR gene, only $14.43 \%$ of the strains $(44 / 305)$ showed resistance to florfenicol, and only $1.64 \%(5 / 305)$ of the strains had MIC values $\geq 512 \mu \mathrm{g} /$ $\mathrm{mL}$. The MIC values between the transformants with cloned floR genes and the clinical isolates were similar (Table 2).

\section{A transferable plasmid carrying the floR gene}

The results of the conjugation experiments for the 23 floR-positive clinical isolates showed that plasmids in

Table 1 Strains and plasmids used in this study

\begin{tabular}{|c|c|c|}
\hline Strain or plasmid & Relevant characteristic(s) ${ }^{a}$ & Reference or source \\
\hline \multicolumn{3}{|l|}{ Strain } \\
\hline KP1 - KP23 & 23 strains carrying the floR gene from 328 clinically isolated K. pneumoniae samples & this study \\
\hline JM109 & Escherichia coli JM109 was used as a host for the PCR product cloning & \\
\hline EC600 & Escherichia coli C600 was used as a host in conjugation experiments; Rf ${ }^{r}$ & \\
\hline ATCC25922 & Escherichia coli ATCC25922 is an FDA clinical isolate & \\
\hline \multicolumn{3}{|l|}{ E. coli carrying plasmid } \\
\hline pMD18-floRs/JM109 & JM109 carrying the pMD18 vector encoding flo $R$ gene regions from 22 floR gene-positive strains & This study \\
\hline pKP5/EC600 & The transconjugant with KP5 plasmid transferred into EC600 & This study \\
\hline pKP6/EC600 & The transconjugant with KP6 plasmid transferred into EC600 & This study \\
\hline pKP18/EC600 & The transconjugant with KP18 plasmid transferred into EC600 & This study \\
\hline \multicolumn{3}{|l|}{ Plasmid } \\
\hline pKP18-125 & KP18 plasmid transferred into EC600 by conjugation and sequenced & This study \\
\hline pMD18 & Cloning vector for the PCR products of floR genes; $A p^{r}$ & TaKaRa \\
\hline
\end{tabular}


Table 2 MIC values for the floR-positive K. pneumoniae strains, transformants expressing cloned floR genes and transconjugants ( $\mu \mathrm{g} /$ $\mathrm{mL})$

\begin{tabular}{|c|c|c|c|c|c|c|}
\hline \multirow[b]{2}{*}{ Name } & \multicolumn{3}{|l|}{ Florfenicol } & \multicolumn{3}{|c|}{ Chloramphenicol } \\
\hline & Clinical isolate & Transformant & Transconjugant & Clinical isolate & Transformant & Transconjugant \\
\hline KP5 & 1024 & 512 & 512 & 256 & 128 & 512 \\
\hline KP6 & 1024 & 256 & 512 & 512 & 256 & 512 \\
\hline KP18 & $>1024$ & 512 & 512 & 512 & 128 & 256 \\
\hline KP23 & 64 & & & 256 & & \\
\hline KP4, 14, 19, 22 & 512 & & & 256 & & \\
\hline KP21 & 512 & & & 128 & & \\
\hline $\mathrm{KP} 3,8,15$ & 1024 & & & 1024 & & \\
\hline $\mathrm{KP} 10,12,13$ & 1024 & & & 256 & & \\
\hline KP11, 20 & 1024 & & & 128 & & \\
\hline $\mathrm{KP} 2,7,9,16,17$ & $>1024$ & & & $>1024$ & & \\
\hline KP1 & $>1024$ & & & 512 & & \\
\hline ATCC25922 & 4 & & & & & \\
\hline JM109 & 4 & & & & & \\
\hline EC600 & 4 & & & & & \\
\hline
\end{tabular}

three donor strains (KP5, KP6 and KP18) were successfully transferred to the recipient. PFGE analysis showed that the wild-type donors KP5, KP6 and KP18 harbored 2, 4 and 2 plasmids, respectively. However, each of the transconjugants (KP5/EC600, KP6/EC600 and KP18/EC600) only harbored the largest plasmid of the donor cells. The results of PCR product sequencing confirmed that floR genes were located on the transferred plasmids. The MIC results showed that the florfenicol and chloramphenicol resistance levels of the transconjugants were similar to those of the donor strains (Table 2).

\section{Clonal relatedness of the floR-positive K. pneumoniae} strains identified by PFGE

PFGE patterns with $\geq 80 \%$ identity were interpreted as closely or possibly related to the outbreak isolates. Of the 23 strains detected, 22 had good fingerprints; one strain (KP21) without clear bands could not be compared. Only two strains (KP5 and KP6) showed similar $\begin{array}{rrrrrrrr}0.31 & 0.40 & 0.50 & 0.80 & 0.70 & 0.80 & 0,90 & 1.00\end{array}$

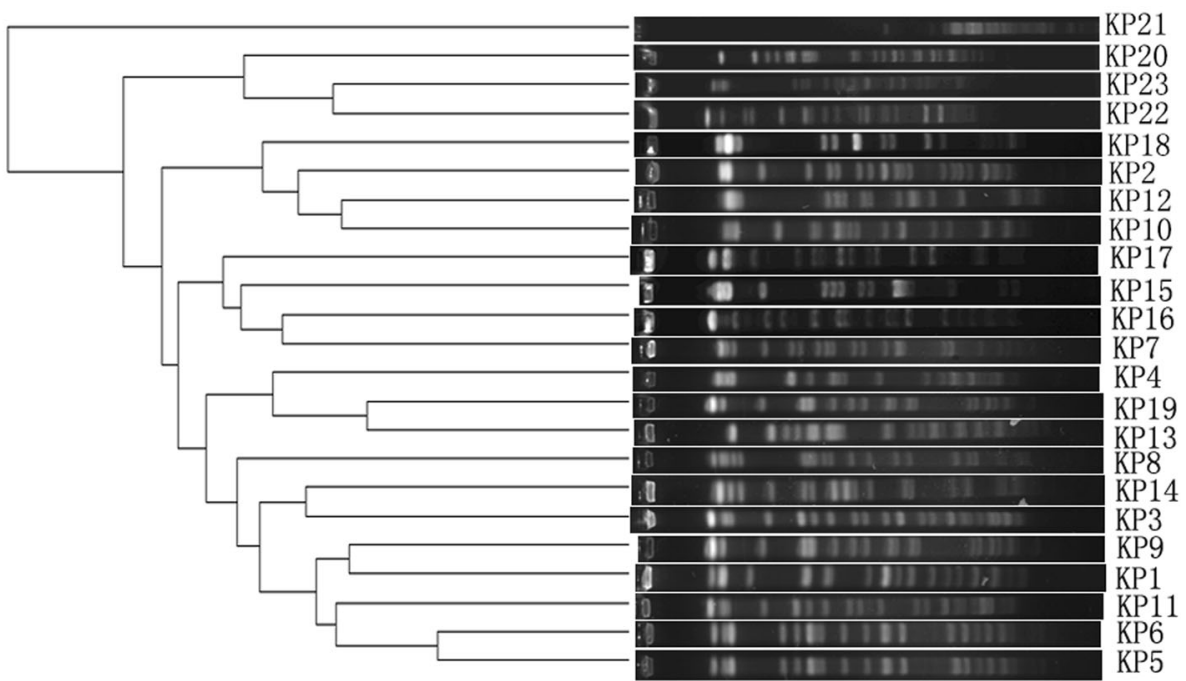

Fig. 1 Pulsed-field gel electrophoresis of Xbal-digested genomic DNA from the 22 floR-positive K. pneumoniae strains. Only one cluster, composed of KP5 and KP6, was determined to be clonally related 
fingerprint patterns, whereas the remaining 20 strains had different genotypes (Fig. 1). KP5 was isolated from a sputum sample of a male patient in the Department of Neurosurgery in March 2014, while KP6 came from a sputum sample of a female patient in the intensive care unit (ICU) in the Department of Brain Surgery in April 2014.

\section{Structure and comparative genomics analysis of floR gene-related regions}

pKP18-125 was 125,329 bp in length. Annotation determined that the plasmid carried one replicon belonging to incompatibility group FII (IncFII) and harbored 164 coding sequences (CDs). The plasmid genome can be divided into 4 regions according to the functions of the ORFs as follows: the variable region, the conjugation region, the transfer leading region and the replication region. The variable region is approximately $40 \mathrm{~kb}$ in length and encodes 42 ORFs, including approximately 20 genes related to drug resistance, 13 recombination-related genes or structures (i.e., integrase and transposase genes and insertion sequences [ISs]) and 9 genes of unknown function. According to the structure of the mobile genetic elements, this region could be roughly divided into six units, including one class 1 integron and five transposons. The floR gene was located in a transposon-like fragment approximately $9 \mathrm{~kb}$ in length (accession number: KY082186) consisting of a conserved gene cluster of lysR-floR-virD2, 5 tnp units and two direct repeats (DRs). In this work, we mainly analyzed the structural characteristics of the $9-\mathrm{kb}$ floR gene-related transposon-like fragment (Fig. 2).
Overall, a total of 105 DNA sequences of approximately $9 \mathrm{~kb}$ in length with the floR gene in their center were retrieved from all floR gene-containing sequences in the NCBI nucleotide database. Of these sequences, 45 were from complete or partial bacterial chromosomes, and 60 were from plasmid sequences. Through a multiple sequence alignment, 27 clusters with identities greater than $80 \%$ were obtained. According to the similarity of the core sequences adjacent to the floR gene, the sequences of these 27 clusters were orthologously analyzed and further clustered into 4 groups (G1- G4), with each group containing 2 subgroups (e.g., G1a and G1b). Group 1 consisted of only 2 sequences (KY082186 and KT282968) that shared approximately $7 \mathrm{~kb}$ in common (Fig. 1 and Table S1).

Eight representative sequences from the eight subgroups (one from each subgroup) are illustrated in Fig. 2 with their accession numbers. Sequences similar to the representative sequences are shown in Additional file 1: Table S1. The results of this orthologous analysis revealed that an approximately 2-kb sequence encoding lysR-floR-virD2 was conserved and present in the majority of the sequences $(79.0 \%, 83 / 105)$. Many of these sequences also shared the same upstream DR and complete or truncated downstream tnp unit (Fig. 1). The 9-kb floR gene-related transposon-like fragment of pKP18-125 in this study showed highest similarity to a $7-\mathrm{kb}$ fragment from the plasmid pEC012 (KT282968). Interestingly, although pKP18-125 was isolated from a K. pneumoniae strain from a patient in South China, pEC012

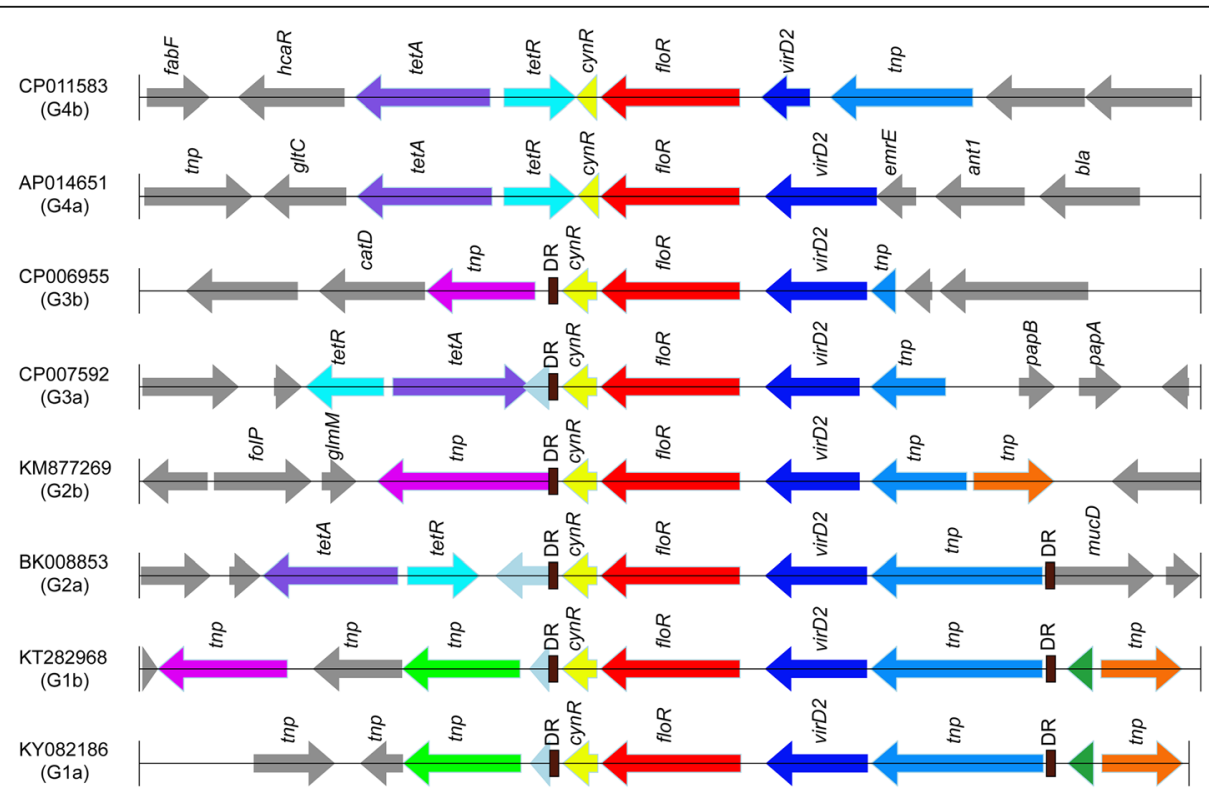

Fig. 2 Structure of the floR gene-related regions. Eight representative sequences from the four groups (one from each subgroup) are presented with their accession numbers. The arrows represent sequence units, and the same units are shown in the same color. The names of the sequence units are indicated over the arrows, with the sequence units of unknown function left blank 
was found in an E. coli isolate from a chicken in North China [41].

\section{Discussion}

In this study, we found that among all the clinical K. pneumoniae isolates detected, $20.42 \%(67 / 328)$ were resistant to florfenicol, of which $7.01 \%$ (23/328) carried the floR gene, but $13.41 \%$ (44/328) were free of the floR gene. A similar report demonstrated a floR gene positivity rate of only $21.8 \%$ (26/119) among 119 florfenicol-resistant gram-negative bacilli from several freshwater Chilean salmon farms [42]. Our MIC results for the 328 strains demonstrated that the floR gene played a key role in the resistance of these bacteria to florfenicol. The floR-positive strains had a much higher resistance rate $(23 / 23,100 \%)$ and much higher MIC values for florfenicol $(22 / 23$, $95.65 \%$ with MIC values $\geq 512 \mu \mathrm{g} / \mathrm{mL}$ ) than the floR-negative strains, which had a resistance rate of $14.43 \%(44 / 305)$ with only $1.64 \%(5 / 305)$ of the strains having MIC values $\geq 512 \mu \mathrm{g} / \mathrm{mL}$. At present, of the nine florfenicol resistance genes, the floR gene is the only known florfenicol resistance gene that has been identified in $K$. pneumoniae strains of either human or animal origin [43]. Five genes $(f e x A, f e x B$, pexA, optrA and $c f r$ ) were mainly identified in gram-positive bacteria [15-17]. The $c f r$ gene has also been occasionally identified in E. coli or Proteus vulgaris [44, 45] and fexA and pexA were once identified in E. coli [44]. The other three genes have only been identified in certain gram-negative bacteria (floRv in Stenotrophomonas maltophilia [46], floSt in Salmonella [47] and estDL136 in E.coli [44]). We hypothesize that other mechanisms, such as exporters and enzymes, in addition to the known florfenicol resistance genes, may also be responsible for florfenicol resistance in gram-negative bacteria including K. pneumoniae.

The floR genes were located on both chromosomes and plasmids amidst various mobile genetic elements, indicating that horizontal transfer of the floR gene occurred among bacteria of different species. The floR gene was identified first on the chromosome of S. typhimurium DT104 (Salmonella typhimurium DT104) and then on a plasmid of E. coli isolate BN10660 [48] and was also identified on the IncC plasmid $\mathrm{R} 55$ harbored by $K$. pneumoniae [13] and on other sources [17, 43]. In $S$. typhimurium DT104, the floR gene was included in a $12.5-\mathrm{kb}$ region with multiple resistance genes. The tet $R$ and tet $A$ tetracycline resistance genes were located downstream of the floR gene and were flanked by two integrons. One integron contained an aadA2 gene and an incomplete sulI resistance gene, and the other harbored a $\beta$-lactamase gene and a complete sulI gene [49]. In pKP18-125, the downstream region was a class 1 integron that contained 5 resistance genes $\left(\operatorname{acc}\left(6^{\prime}\right)\right.$, arr2, etc.) and was different from the 12.5-kb region of the $S$. typhimurium DT104 chromosome. Interestingly, the sequence most similar to the floR-containing fragment on pKP18-125 from a clinical Klebsiella pneumoniae isolate was located on pEC012 (KT282968), a plasmid from an E. coli strain isolated from a chicken [50]. This finding suggests that horizontal transfer of the floR-containing fragment occurred between bacteria of animal and human origins.

Our PFGE analysis revealed that two floR-positive strains (KP5 and KP6) had similar PFGE profiles. They were isolated from the same sample type (sputum) but were found in different hospitalized patients during different time periods. Some $K$. pneumoniae strains carrying resistance genes were previously reported to have caused outbreaks in European countries, indicating the potential risk of the spread of resistance genes through bacterial outbreaks, especially those caused by bacteria with resistance plasmids [51]. Although the relationship between the two strains carrying floR is still in question, effort should be made to avoid any pathogen outbreaks in hospital environments.

\section{Conclusions}

Our study demonstrated that $20.42 \%(67 / 328)$ of the clinical $K$. pneumoniae isolates were resistant to florfenicol, but only $7.01 \%(23 / 328)$ carried the floR gene. The $f l o R$ gene was related to a transposon-like sequence and located on a conjugative plasmid. The most similar sequence to the floR-containing fragment on pKP18-125 was that a fragment on pEC012 in an E. coli strain isolated from a chicken. This finding indicates that resistance genes in animal pathogens might be disseminated to human pathogens. The dissemination of resistance genes from animals to humans reflects the risk to human health of antimicrobial agent use in animals. In addition, these results highlight the critical need to consistently implement effective strategies to prevent transmission and infection. Combating antibiotic-resistant bacteria supports patient care, agriculture, economic growth and national security.

\section{Additional file}

Additional file 1: Table S1 Grouping of 105 floR gene containing sequences and their origins. (PDF $67 \mathrm{~kb}$ )

\section{Abbreviations}

Ap: Ampicillin; BLAST: Basic local alignment search tool; ICU: Intensive care unit; MICs: Minimum inhibitory concentrations; PFGE: Pulsed-field gel electrophoresis; Rf: Rifampin

\section{Acknowledgments}

The authors would like to acknowledge all study participants and individuals who contributed to the study. 


\section{Funding}

This work was funded by grants from the Natural Science Foundation of Zhejiang Province (LY14C060005 and LQ17H190001), the Science and Technology Foundation of Zhejiang Province (2015C33196) and the National Natural Science Foundation of China (81401702, 81501808 and 81501780).

\section{Availability of data and materials}

The data used in this paper were deposited in the NCBI database

\section{Authors' contributions}

$J L, J Z, L X, Y L, T Z$ and $S L$ collected the strains and performed the experiments. $K L, W Z$ and $L N$ analyzed the experimental results. PL, TX and HY performed the bioinformatics analysis. JL, CC and QB wrote the manuscript. CC and QB designed the experiments. All authors read and approved the final manuscript.

\section{Ethics approval and consent to participate}

Not applicable.

\section{Consent for publication}

Not applicable.

\section{Competing interests}

The authors declare that they have no competing interests.

\section{Publisher's Note}

Springer Nature remains neutral with regard to jurisdictional claims in published maps and institutional affiliations.

\section{Author details}

${ }^{1}$ School of Medicine and Health, Lishui University, Lishui 323000, China. ${ }^{2}$ School of Laboratory Medicine and Life Sciences/Institute of Biomedical Informatics, Wenzhou Medical University, Wenzhou 325035, China. ${ }^{3}$ The Second Affiliated Hospital, Wenzhou Medical University, Wenzhou 325035, China.

\section{Received: 5 August 2017 Accepted: 27 September 2018}

\section{Published online: 01 November 2018}

\section{References}

1. Apley MD. Clinical evidence for individual animal therapy for papillomatous digital dermatitis (hairy heel wart) and infectious bovine pododermatitis (foot rot). Vet Clin North Am Food Anim Pract. 2015;31:81-95. https://doi. org/10.1016/j.cvfa.2014.11.009.

2. Gaffney D, Foster T. Chloramphenicol acetyltransferases determined by $R$ plasmids from gram-negative bacteria. J Gen Microbiol. 1978;109:351-8.

3. Schwarz S, Kehrenberg C, Doublet B, Cloeckaert A. Molecular basis of bacterial resistance to chloramphenicol and florfenicol. FEMS Microbiol Rev. 2004;28:519-42. https://doi.org/10.1016/j.femsre.2004.04.001

4. Kucerova Z, Hradecka H, Nechvatalova K, Nedbalcova K. Antimicrobial susceptibility of Actinobacillus pleuropneumoniae isolates from clinica outbreaks of porcine respiratory diseases. Vet Microbiol. 2011;150:203-6. https://doi.org/10.1016/j.vetmic.2011.01.016.

5. Chang SK, Lo DY, Wei HW, Kuo HC. Antimicrobial resistance of Escherichia coli isolates from canine urinary tract infections. J Vet Med Sci. 2015;77:5965. https://doi.org/10.1292/jvms.13-0281

6. Geng Y, Wang KY, Huang XL, Chen DF, Li CW, Ren SY, et al. Streptococcus agalactiae, an emerging pathogen for cultured ya-fish, Schizothorax prenanti, in China. Transbound Emerg Dis. 2012;59:369-75. https://doi.org/ 10.1111/j.1865-1682.2011.01280.x

7. Sun F, Zhou D, Wang Q, Feng J, Feng W, Luo W, et al. Genetic characterization of a novel blaDIM-2-carrying megaplasmid p12969-DIM from clinical Pseudomonas putida. J Antimicrob Chemother. 2016;71:909-12. https://doi. org/10.1093/jac/dkv426.

8. de Jong A, Thomas V, Simjee S, Moyaert H, El Garch F, Maher K, et al. Antimicrobial susceptibility monitoring of respiratory tract pathogens isolated from diseased cattle and pigs across Europe: the VetPath study. Vet Microbiol. 2014;172:202-15. https://doi.org/10.1016/j.vetmic.2014.04.008.

9. Dayao DA, Gibson JS, Blackall PJ, Turni C. Antimicrobial resistance in bacteria associated with porcine respiratory disease in Australia. Vet Microbiol. 2014; 171:232-5. https://doi.org/10.1016/j.vetmic.2014.03.014
10. Kim E, Aoki T. Sequence analysis of the florfenicol resistance gene encoded in the transferable R-plasmid of a fish pathogen, Pasteurella piscicida. Microbiol Immunol. 1996;40:665-9.

11. Arcangioli MA, Leroy-Setrin S, Martel JL, Chaslus-Dancla E. A new chloramphenicol and florfenicol resistance gene flanked by two integron structures in Salmonella typhimurium DT104. FEMS Microbiol Lett. 1999;174:327-32.

12. Mather AE, Reid SW, Maskell DJ, Parkhill J, Fookes MC, Harris SR, et al. Distinguishable epidemics of multidrug-resistant Salmonella typhimurium DT104 in different hosts. Science. 2013;341:1514-7. https://doi.org/10.1126/ science.1240578.

13. Cloeckaert A, Baucheron S, Chaslus-Dancla E. Nonenzymatic chloramphenicol resistance mediated by IncC plasmid R55 is encoded by a floR gene variant. Antimicrob Agents Chemother. 2001;45:2381-2. https:// doi.org/10.1128/AAC.45.8.2381-2382.2001.

14. Wang Y, Zhang W, Wang J, Wu C, Shen Z, Fu X, et al. Distribution of the multidrug resistance gene $\mathrm{cfr}$ in Staphylococcus species isolates from swine farms in China. Antimicrob Agents Chemother. 2012;56:1485-90. https://doi. org/10.1128/AAC.05827-11.

15. Lang KS, Anderson JM, Schwarz S, Williamson L, Handelsman J, Singer RS. Novel florfenicol and chloramphenicol resistance gene discovered in Alaskan soil by using functional metagenomics. Appl Environ Microbiol. 2010;76:5321-6. https://doi.org/10.1128/AEM.00323-10.

16. Couto N, Belas A, Rodrigues C, Schwarz S, Pomba C. Acquisition of the fexA and $\mathrm{cfr}$ genes in Staphylococcus pseudintermedius during florfenicol treatment of canine pyoderma. J Glob Antimicrob Resist. 2016;7:126-7. https://doi.org/10.1016/j.jgar.2016.08.008

17. Liu H, Wang Y, Wu C, Schwarz S, Shen Z, Jeon B, et al. A novel phenicol exporter gene, fexB, found in enterococci of animal origin. J Antimicrob Chemother. 2012;67:322-5. https://doi.org/10.1093/jac/dkr481.

18. Tao W, Lee MH, Wu J, Kim NH, Kim JC, Chung E, et al. Inactivation of chloramphenicol and florfenicol by a novel chloramphenicol hydrolase. Appl Environ Microbiol. 2012;78:6295-301. https://doi.org/10.1128/AEM. 01154-12.

19. Gabida M, Gombe NT, Chemhuru M, Takundwa L, Bangure D, Tshimanga M. Foodborne illness among factory workers, Gweru, Zimbabwe, 2012: a retrospective cohort study. BMC Res Notes. 2015;8:493. https://doi.org/10. 1186/s13104-015-1512-2.

20. Lai J, Wang Y, Shen J, Li R, Han J, Foley SL, et al. Unique class 1 integron and multiple resistance genes co-located on IncHI2 plasmid is associated with the emerging multidrug resistance of Salmonella Indiana isolated from chicken in China. Foodborne Pathog Dis. 2013;10:581-8. https://doi.org/10. 1089/fpd.2012.1455

21. da Silva GC, Rossi CC, Santana MF, Langford PR, Bosse JT, Bazzolli DMS p518, a small floR plasmid from a south American isolate of Actinobacillus pleuropneumoniae. Vet Microbiol. 2017;204:129-32. https://doi.org/10.1016/ j.vetmic.2017.04.019.

22. Anantham S, Harmer CJ, Hall RM. p39R861-4, a type 2 a/C2 plasmid carrying a segment from the a/C1 plasmid RA1. Microb Drug Resist. 2015;21:571-6. https://doi.org/10.1089/mdr.2015.0133.

23. Davis GS, Price LB. Recent research examining links among Klebsiella pneumoniae from food, food animals, and human extraintestinal infections. Curr Environ Health Rep. 2016:3:128-35. https://doi.org/10.1007/s40572-0160089-9.

24. Martin RM, Bachman MA. Colonization, infection, and the accessory genome of Klebsiella pneumoniae. Front Cell Infect Microbiol. 2018;8:4. https://doi.org/10.3389/fcimb.2018.00004

25. Kikuchi N, Kagota C, Nomura T, Hiramune T, Takahashi T, Yanagawa R. Plasmid profiles of Klebsiella pneumoniae isolated from bovine mastitis. Vet Microbiol. 1995:47:9-15.

26. Brisse S, Duijkeren E. Identification and antimicrobial susceptibility of 100 Klebsiella animal clinical isolates. Vet Microbiol. 2005;105:307-12. https://doi. org/10.1016/j.vetmic.2004.11.010

27. Tzouvelekis LS, Markogiannakis A, Psichogiou M, Tassios PT, Daikos GL. Carbapenemases in Klebsiella pneumoniae and other Enterobacteriaceae: an evolving crisis of global dimensions. Clin Microbiol Rev. 2012;25:682-707. https://doi.org/10.1128/CMR.05035-11.

28. Ying J, Wang $H$, Bao B, Zhang $Y$, Zhang J, Zhang $C$, et al. Molecular variation and horizontal gene transfer of the homocysteine methyltransferase gene mmuM and its distribution in clinical pathogens. Int J Biol Sci. 2015:11:11-21. https://doi.org/10.7150/ijbs.10320. 
29. Arcangioli MA, Leroy-Setrin S, Martel JL, Chaslus-Dancla E. Evolution of chloramphenicol resistance, with emergence of cross-resistance to florfenicol, in bovine Salmonella typhimurium strains implicates definitive phage type (DT) 104. J Med Microbiol. 2000;49:103-10. https://doi.org/10. 1099/0022-1317-49-1-103.

30. Clinical and Laboratory Standards Institute. Performance standards for antimicrobial susceptibility testing; 27 th informational supplement. In: Document; 2017. p. M100-S27

31. Wasyl D, Hoszowski A, Zajac M, Szulowski K. Antimicrobial resistance in commensal Escherichia coli isolated from animals at slaughter. Front Microbiol. 2013:4:221. https://doi.org/10.3389/fmicb.2013.00221.

32. Katoh K, Standley DM. MAFFT multiple sequence alignment software version 7: improvements in performance and usability. Mol Biol Evol. 2013, 30:772-80. https://doi.org/10.1093/molbev/mst010

33. Roussel S, Felix B, Vingadassalon N, Grout J, Hennekinne JA, Guillier L, et al. Staphylococcus aureus strains associated with food poisoning outbreaks in France: comparison of different molecular typing methods, including MLVA. Front Microbiol. 2015;6:882. https://doi.org/10.3389/fmicb.2015.00882.

34. Yi H, Xi Y, Liu J, Wang J, Wu J, Xu T, et al. Sequence analysis of pKF3-70 in Klebsiella pneumoniae: probable origin from R100-like plasmid of Escherichia coli. PLoS One. 2010;5:e8601. https://doi.org/10.1371/journal. pone.0008601

35. Delcher AL, Bratke KA, Powers EC, Salzberg SL. Identifying bacterial genes and endosymbiont DNA with glimmer. Bioinformatics. 2007;23:673-9. https://doi.org/10.1093/bioinformatics/btm009.

36. Petkau A, Stuart-Edwards M, Stothard P, Van Domselaar G. Interactive microbial genome visualization with GView. Bioinformatics. 2010;26:3125-6. https://doi.org/10.1093/bioinformatics/btq588

37. Remm M, Storm CE, Sonnhammer EL. Automatic clustering of orthologs and in-paralogs from pairwise species comparisons. J Mol Biol. 2001;314 1041-52. https://doi.org/10.1006/jmbi.2000.5197.

38. Hu L, Zhong Q, Tu J, Xu Y, Qin Z, Parsons C, et al. Emergence of blaNDM-1 among Klebsiella pneumoniae ST15 and novel ST1031 clinical isolates in China. Diagn Microbiol Infect Dis. 2013;75:373-6. https://doi.org/10.1016/j. diagmicrobio.2013.01.006.

39. Xu T, Ying J, Yao X, Song Y, Ma P, Bao B, et al. Identification and characterization of two novel Bla(KLUC) resistance genes through largescale resistance plasmids sequencing. PLoS One. 2012;7:e47197. https://doi. org/10.1371/journal.pone.0047197.

40. Rice LB, Carias LL, Bonomo RA, Shlaes DM. Molecular genetics of resistance to both ceftazidime and beta-lactam-beta-lactamase inhibitor combinations in Klebsiella pneumoniae and in vivo response to beta-lactam therapy. J Infect Dis. 1996;173:151-8

41. Li XS, Wang GQ, Du XD, Cui BA, Zhang SM, Shen JZ. Antimicrobial susceptibility and molecular detection of chloramphenicol and florfenicol resistance among Escherichia coli isolates from diseased chickens. J Vet Sci. 2007:8:243-7.

42. Fernandez-Alarcon C, Miranda CD, Singer RS, Lopez Y, Rojas R, Bello H, et al. Detection of the floR gene in a diversity of florfenicol resistant gramnegative bacilli from freshwater salmon farms in Chile. Zoonoses Public Health. 2010;57:181-8. https://doi.org/10.1111/j.1863-2378.2009.01243.x.

43. Gordon L, Cloeckaert A, Doublet B, Schwarz S, Bouju-Albert A, Ganiere JP, et al. Complete sequence of the floR-carrying multiresistance plasmid pAB5S9 from freshwater Aeromonas bestiarum. J Antimicrob Chemother. 2008;62: 65-71. https://doi.org/10.1093/jac/dkn166.

44. Zhang A, Yang Y, Wang H, Lei C, Xu C, Guan Z, et al. Prevalence of sulfonamide and Florfenicol resistance genes in Escherichia Coli isolated from yaks (Bos Grunniens) and herdsmen in the Tibetan pasture. J Wildl Dis. 2015;51:626-33. https://doi.org/10.7589/2014-09-234.

45. Wang Y, Wang Y, Wu CM, Schwarz S, Shen Z, Zhang W, et al. Detection of the staphylococcal multiresistance gene $\mathrm{cfr}$ in Proteus vulgaris of food animal origin. J Antimicrob Chemother. 2011;66:2521-6. https://doi.org/10. 1093/jac/dkr322

46. He T, Shen J, Schwarz S, Wu C, Wang Y. Characterization of a genomic island in Stenotrophomonas maltophilia that carries a novel floR gene variant. J Antimicrob Chemother. 2015;70:1031-6. https://doi.org/10.1093/ jac/dku491.

47. Alessiani A, Sacchini L, Pontieri E, Gavini J, Di Giannatale E. Molecular typing of Salmonella enterica subspecies enterica serovar Typhimurium isolated in Abruzzo region (Italy) from 2008 to 2010. Vet Ital. 2014;50:31-9. https://doi. org/10.12834/Netlt.1304.07
48. Cloeckaert A, Baucheron S, Flaujac G, Schwarz S, Kehrenberg C, Martel $J$, et al. Plasmid-mediated florfenicol resistance encoded by the floR gene in Escherichia coli isolated from cattle. Antimicrob Agents Chemother. 2000:44:2858-60.

49. Cloeckaert A, Sidi Boumedine K, Flaujac G, Imberechts H, D'Hooghe I, Chaslus-Dancla E. Occurrence of a Salmonella enterica serovar typhimurium DT104-like antibiotic resistance gene cluster including the floR gene in S. enterica serovar agona. Antimicrob Agents Chemother. 2000;44:1359-61.

50. Pan YS, Zong ZY, Yuan L, Du XD, Huang H, Zhong XH, et al. Complete sequence of pEC012, a multidrug-resistant Incl1 ST71 plasmid carrying Bla CTX-M-65, rmtB, fosA3, floR, and ogxAB in an avian Escherichia coli ST117 strain. Front Microbiol. 2016;7:1117. https://doi.org/10.3389/fmicb.2016. 01117.

51. Hong JS, Yoon EJ, Lee H, Jeong SH, Lee K. Clonal dissemination of Pseudomonas aeruginosa sequence type 235 isolates carrying blalMP-6 and emergence of blaGES-24 and blalMP-10 on novel Genomic Islands PAGI-15 and -16 in South Korea. Antimicrob Agents Chemother. 2016;60:7216-23. https://doi.org/10.1128/AAC.01601-16
Ready to submit your research? Choose BMC and benefit from:

- fast, convenient online submission

- thorough peer review by experienced researchers in your field

- rapid publication on acceptance

- support for research data, including large and complex data types

- gold Open Access which fosters wider collaboration and increased citations

- maximum visibility for your research: over $100 \mathrm{M}$ website views per year

At BMC, research is always in progress.

Learn more biomedcentral.com/submissions 